\title{
Global Cities and the Ends of Globalism
}

\begin{abstract}
The global city has been both a product and driver of contemporary globalization. But today the global city is under threat from at least two directions. The first threat is internal to the global city form itself. Global cities have internalized the contradictory forces of market liberalism. Despite their astonishing economic growth over the last four decades, they have, at the same time, become deeply divided and polarized in ways that threaten the integrity of the urban fabric. They amplify and focus the contradictions of free market capitalism, and provide the spaces of centrality in which political struggle will play out. The second source of threat comes from the weakening and possible collapse of liberal world order, the resurgence of nationalism, and the prospect of the end of the contemporary form of globalisation. This article argues that global cities are at a point of crisis, because they embody an unstable form of global market society. In order to survive in a 'global' form, they will need to evolve by repurposing some of the political, economic and governance capacities that they have been developing over the last four decades. The article asks: what capacities and capabilities have global cities generated, and how might they be reoriented in the creation of alternative global city futures?
\end{abstract}

\section{Introduction}

In response to a number of indicators that contemporary globalization is under threat, this special issue of New Global Studies asks what happens to cities when globalization unravels. This question is significant because of the signs that the forms of global order that have structured world politics for many decades now are under threat from various sources. In particular, we might point to the rise of protectionist and nationalist sentiments, a shift towards authoritarian leadership, the rise of right wing political parties and movements, the roll back of support for the international institutions that have underpinned liberal order, and the ongoing instabilities of global capitalism.

Indeed, there is much debate at present about the future of liberal world order. And, although we have no definitive answer on what future direction these trends may take, these symptoms make the question of what form of urban and international order might succeed present arrangements an urgent one. The end of at least four decades of globalization would mean a very profound shift in the nature of the international system. It would mean a possibly irredeemable fracturing of the liberal world order that has underpinned geopolitical stability since the post World War II period, and expanded its reach after the Cold War. It would mean a distinctive shift in the mode of capitalist regulation, and a reassessment of the merits of the neoliberal form. And, as I will argue, the end of contemporary forms of globalism must also mean the end of the global city. 
I do not mean, of course, that the major cities of the world would cease to play a crucial role, shrink or disappear. Short of a catastrophic war, the twenty-first century will be the urban century. The forms of planetary urbanism and globe spanning infrastructures that have been developed over centuries, and integrated rapidly over the last few decades, are here to stay. The point I wish to make is, rather, that the historically distinctive form of city that we have come to call the 'global city' is intrinsically bound up with the specific form of global free market political economy that has driven contemporary globalization, and that if the form of global political economy were to be transformed or modified, then so would the global city be transformed. Here I use the term 'global city' not to refer to a specific object (a particular city, or set of cities), but as a concept, designed to identify the relationship between urbanization and a particular historically specific form of globalized capitalism. ${ }^{1}$ The concept specifies a process of urbanisation that gives rise to certain urban and infrastructural characteristics, which I will specify.

So, in this sense, the 'de-globalized' city would necessarily be a different form of urban life to that identified and analyzed by the global city theorists, and the extensive research project they have developed over the last thirty years (Acuto 2011). It would be a city retaining many of the capacities and capabilities of the contemporary 'global city'. But those capacities and capabilities would be oriented to different ends, and plugged into different relationships. ${ }^{2}$

I want to suggest in this article that such a shift in the nature of the global city is almost inevitable. The global city must transform into something new, because its very nature is unstable and unsustainable. Because global cities draw their nature and form from the wider forms of political and economic order that have generated the global free market, they also partake in the inherent contradictions and instabilities of that order. These are exactly the contradictions and instabilities that have brought the question of the end of globalism and the de-globalization of the city into view. So, although there is at present insufficient evidence to say that liberal order and contemporary globalization are unraveling or in terminal decline, there are sufficient logical and historical grounds to expect that the imbrication of neoliberal capitalism and urbanization is generating unsustainable contradictions, tensions and instabilities that must be resolved by the emergence of a new model, and a new urban expression for that model. In particular, I will draw partially upon Karl Polanyi's (1957) analysis of what happened to the political project to implement an international market civilization in the nineteenth-century, and the parallels his analysis holds for

\footnotetext{
${ }^{1}$ My use of the term 'global city' here is in line with original 'global city' theorists, such as Sassen (1991), who used it as a heuristic device to interrogate the relationship between a new urban form and global capitalism. In this sense, it is a concept tied to a particular mode of economic regulation (Soja 2000), which makes it conducive to the linkage I make here between urban form and the contradictions of the global free market. There are, of course, multiple ways to approach urbanization today, and the concept of 'planetary urbanization' offered by Brenner and Schmid (2000) offers a more allencompassing linkage. But for my purposes here it doesn't offer a fine-grained enough tool to pick out the distinctive components forming in global city nodes and their networks.

${ }^{2}$ I will draw on the concept of 'assemblage' as a tool to think about the ways in which the historical transformation of cities, and the broader international systems of which they are an element, can take place. There is a diversity of approaches to assemblage thinking, and I refer the reader to Acuto and Curtis (2014) for an overview of the promise and pitfalls of this literature. I focus particularly on Sassen's (2007) appropriation of the concept. While Sassen's usage is idiosyncratic, it does also have a range of overlaps with the broader tradition of assemblage thinking, and is in no way incompatible with other theoretical formulations.
} 
contemporary attempts to do the same, extending his analysis to the urban expression of this project we find in the formation of global cities.

In this sense, we might see the global city as a form of chrysalis; one that has developed over the last four decades, incubating and nurturing new economic and political capacities and capabilities as well as new technological forms, but with a limited life-span; an urban form that must in turn give birth to new urban forms that will have a different character. There is no teleology determining the forms of urban life that may emerge, no necessary 'arc of history that bends towards connectivity', as Khanna (2016) has argued, for example. Khanna's optimism about an emerging 'network civilization' is but another iteration of the liberal dream of a market utopia that pays no heed to the contradictions of global capitalism. Several models and various futures are available, some deeply regressive and dystopian, others progressive, others chaotic. But I will argue that those cities around the world that we now call, with increasingly unthinking habit, global cities, must be but a stage in the evolution of both the urban system and the wider international system.

The article proceeds in three stages. The first section examines the link between the global city form and neoliberal market led globalization, justifying the claim that a shift in the form of global political economy must mean a transformation of the global city into a new, as yet unknown, form.

The second section examines the sources of threat to the existing global city, alongside some of the new governance capacities cities have acquired in this period. The first source of threat is internal to the global city form itself. Global cities have internalized the contradictory forces of market liberalism. Despite their astonishing economic growth over the last four decades, they have, at the same time, become deeply divided and polarized in ways that threaten the integrity of the urban fabric. They amplify and focus the contradictions of global free market capitalism, and provide the spaces of centrality in which political struggle will play out. The second source of threat comes from the weakening and possible collapse of liberal world order, the resurgence of nationalist and protectionist sentiments, and the prospect of the end of the contemporary form of globalisation via the dismantling of its geopolitical framework of liberal hegemonic power. These threats play out in emerging tensions between the city and the state, and the city and the market.

The final section argues that the time is approaching when the global city 'chrysalis' will incubate a new form of city with different characteristics, as the technological and governance capacities and capabilities developed over the last four decades of market globalisation are refocused and reconnected to generate new forms of urban assemblages. Space allows only a brief sketch, but a larger research agenda beckons, linking assemblage thinking, urban transformation and international change. The future forms of urban life are open, but the essay ends by identifying a number of possible futures based upon existing trends.

\section{Global Cities, Liberal Order and Market Civilization}

Contemporary global cities are a product of contemporary globalization. They are the urban expression, and part of the morphological form, of the specific type of 
globalization that began to take shape in the 1970s, as the international political economy was redesigned along neoliberal principles by a group of powerful states, led by the hegemonic power of the United States (Soja 2000; Panitch and Gindin 2013; Gill 2003). ${ }^{3}$ Although global city formation was not an explicit aim of such policies, it has been an unintended by-product of state strategy (Curtis 2016). Leading cities have been able to develop agglomeration economies that have crystalized unprecedented concentrations of wealth, power and resources from the new openness of global capital markets (Polèse 2011). As vital command and control nodes in an increasingly integrated global market, there has been an unprecedented expansion of the urban, such that we may now speak of a condition of planetary urbanism (Brenner and Schmidt 2011) - the incorporation of the entire planet and all its multi-form environments and habitats into one vast urban system, eradicating the notional division between nature and artifice that had been one of the hallmarks of modern thought (Latour 1993; Bellamy Foster 2000).

The 'global city' is but one manifestation of contemporary urbanism; a concept designed to pick out the specific role that certain cities now play as nodal points in a global market economy, as well as the points of articulation and connectivity of the material exoskeleton of what we might call an emerging market civilization under free market globalization. It was this emerging role that the global city theorists elucidated in their various theoretical and empirical explorations of the changing nature of cities from the 1980s onwards (see Brenner and Keil 2006, for an overview). In particular, in Sassen's (1991) seminal statement, we find the insight that global cities had come to play a critical role in economic governance in a global marketplace, in which decisions about the allocation of capital and the organization of production had come to rest more in the hands of private non-state actors, such as the multi-national and trans-national firms who locate in global cities. The increasing sophistication of this decentralized system of economic governance was accelerated by the clustering of corporate actors into the central business districts of cities, and the implosion of resources of human capital and technological capacity into those spaces (Glaeser 2011). Global cities came to take their place in an emerging, and largely unanticipated and unpredicted, regime of global economic governance. It was at this point that they began to develop new capacities and capabilities, as the international system tilted in a new direction.

Such cities were transformed as a result. Wealth and power poured into these hubs of economic governance and resource allocation, generating spectacular skylines, and gentrifying the urban landscape. The downtowns of many such cities around the world began to take on recognizably similar characteristics. And they were connected together in scale jumping networks, via emerging technologies of connectivity. At the same time such cities began to stretch across vast tracks of transnational space,

\footnotetext{
${ }^{3}$ Although there are questions about the cohesiveness of neoliberalism as an ideology and political project, Gilbert (2013,8-12) argues that there is enough consistency for neoliberalism to be considered to be coherent as 'an aggregation of ideas, a discursive formation, an over-arching ideology, a governmental programme, and entrepreneurial modes of relation across the public and commercial sectors'. Its features incorporate; 'privatization of public assets, contraction and centralisation of democratic institutions, reductions in progressive taxation, restrictions on labour organisation, labour market deregulation, active encouragement of competitive forces and entrepreneurial modes of relation across the public and commercial sectors'.
} 
integrating regions, generating immense urban corridors, and inscribing in space material patterns unknown in the historical record.

But, at the same time, as we now know, a dark side of the global city emerged, largely beyond the scope of the initial research project of the original global city theorists, but increasingly pressing upon the attention of those considering the broad nature and meaning of contemporary urban change. This dark side was but the other countenance of the Janus-faced process of urbanization under the global free market, an intrinsic part of the polarization that generated the wealth and power concentrated in the global city node. Contemporary urbanism is equally to be characterized by the production of unprecedented slums and informal settlements in the global south (Davis 2006; McGuirk 2014), the drivers of which can often be traced to the workings and policies of the same International Organisations that form a part of the 'Washington Consensus'. At the same time, the global city node is itself riven by inequality and expulsions, its very fabric rent by a process of fracturing and splintering (Graham and Marvin 2000), as the neoliberal creed privatizes space and infrastructure, and diminishes the urban commons (Harvey 2012; Sassen 2014). These exclusions and expulsions, which simultaneously generate the global city core, are, then, inseparable from the logics of the historically specific political economy that gives it form. The contemporary urban system, in its entirety, might be read as a form of structural violence inherent to the process of global city formation under the neoliberal mode of capitalist regulation.

The contradictions of this form of planetary urbanism are, then, but a manifestation in space of the contradictions of neoliberal capitalism and the global free market (Lefebvre 1991). Urban forms throughout history have always reflected the social relations of their time, whether this be the temple centric cities of ancient Mesopotamia, the tenement packed city centers of the Victorian industrial city, or the other myriad material forms that urban life has taken across time and space (Soja 2000). The global city is but one more production of space, whose specific form has a moment of origin, and whose contradictions will mean that it will have its own moment of metamorphosis.

I have noted how the economic restructuring of the 'Bretton Woods' system in the 1970s was crucial in bringing forth global city formation. But, as any attempt to build a 'free' market always rests upon a bedrock of political power (Polanyi 1957), we must look beyond one-dimensional economistic arguments to the broader configurations of both state and state system to understand the origins of such cities, and their possible transformation. Here, we must note the role of US hegemonic power in projecting a specific set of neoliberal values onto the restructured global political economy (Panitch and Gindin 2013). It is no coincidence that the period of accelerated global city formation, and the rise of a scholarly and public discourse about the transformation of cities, occurs in the period of peak US power in the 1990s - the unipolar moment, where the second and third worlds were being integrated into the liberal economic order. As Polanyi argued, there is no such thing as a 'free market'. Both at the national and international scale its appearance is always a facet of state power. The global market that has emerged over the past four decades is no exception. The global city has also been, then, an outcome of state power employed for the specific end of generating a global market civilization (Curtis 2016). The question is, then: if both the economic and political pillars supporting the emergence 
of global cities are both showing signs of exhaustion and decay, what becomes of the global city?

\section{Sources of Instability and Transformation}

Firstly, the geopolitical component, although generally not analyzed in discussions of either the origins or future of global cities, is absolutely critical to any question of whether we will see a 'de-globalizing city'. There is much contemporary debate on whether a period of liberal world order is coming to a close (see Ferguson and Zakaria 2017 for opposing positions). With the advent of the Trump Presidency in the US, the possibility of retrenchment, isolationism and the putting up of walls, both real and metaphorical, have characterized public debate in the very heartland of liberal hegemony. There have been a succession of waves of reaction to some of the iniquities of contemporary globalization: the rise of right wing political movements in both the US and Europe, coupled with the increasing assertiveness of authoritarian regimes such as Russia and China, who scent opportunity in the decay of a form of world order in which they have never had a central voice. Such developments signal turbulent times for the form of global order (Hurrell 2007; Ikenberry 2011) that has characterized the post-war era, and has enabled and shaped the global city.

Secondly, instability in the geopolitical pillar is accompanied by uncertainty and structural weakness in the economic pillar. The 2008 financial crisis has made it clear that the neoliberal mode of capitalist regulation is inherently volatile and unstable, and that its real world performance has failed to match up to the hopes of its ideologues. A lack of real reform to the system that produced the crisis has meant that such instabilities will not go away, and will reappear in some new form. At the same time, there has been a growing perception of the inherent injustices and inequalities of a form of political economy that fails to deliver even on its most basic promises. While the rise of the right across Europe, and of anti-globalist tendencies in the British decision to leave the European Union, are expressions of this tendency, more progressive forms of resistance can also be found in examples such as the Occupy movements.

The global city has become a central stage on which these political and economic tensions can play out. In particular, we see conflicts arising around the relationship between the city and the state, and the relationship between the city and the market. We should expect these tensions to rise in future years, as the reactions against market society increase, and as the city begins to realize that its new found political and governance capacities offer an alternative source of power and influence to the nation-state.

It appears that the relationship between the city and the state is in a process of recalibration. Indeed, this relationship is always historically in flux in many ways (Taylor 2013). Over the last few centuries the ascendency of the Westphalian form of the state - one based upon hard territorial boundaries and the concept of national sovereignty - has made the city seem to be only a part of a national urban system, internalized by, and subordinate to, the state. But we now appear to be living through a distinct shift in this relationship between city and state, as a result of the new capacities and capabilities that cities have gained. These exist in the sphere of 
economic governance, as the original global city theorists have made clear. But cities are also exhibiting novel forms of political governance capacity that have begun to bypass the state in some instances. Together these capacities offer new avenues for tipping the system onto another path.

The primary manifestation of new capacities for political governance for cities can be seen in their impact on the changing nature of global governance. Cities have been using their newfound reach at the transnational level to generate a growing range of transnational municipal governance networks. Empirical investigations by the City Leadership Laboratory at University College London have mapped over 200 city-tocity networks, many founded in the last few decades (Acuto and Rayner 2016). The most prominent example here has been the C40 Climate Leadership Initiative, ${ }^{4}$ but urban governance networks encompass security, health, public safety and many other areas, and cities are an increasingly important part of the UN system. Such transnational reach exhibits a specific form of city power: the ability to convene and coordinate networks in the pursuit of particular goals. The diversity of private and civil society actors enrolled within C40 Climate Leadership Initiative are an example of this (Boutelegier 2013).

Here cities increasingly offer a parallel system to states, continuing to deepen transnational networks that often bypass central government. The power of this form of networking, legitimated by the ability of cities to operate at multiple scales, from the mundane, everyday and local, up through to the largest planetary forms of governance, poses questions about the future of global order (Acuto 2013). It offers the building blocks for new forms of multi-scalar politics, and the prospect of a 'tipping point' that can take us beyond the territorial limits of state sovereignty. This is recognized in recent discussions about possibilities for new forms of political organization, whether this be a Global Parliament of Mayors (Barber 2013), or a new Transnational Municipal Confederalism (Bookchin 1992). These would be an example of the system 'jumping tracks', as new multi-scalar political assemblages form from the redirection of existing urban capacities constructed in the era of state territoriality.

To a degree unseen before, the state's overall legitimacy and governance capacity is, then, being challenged by a new political unit: or, a very old political unit, endowed with twenty-first century capacities that give it an unprecedented transnational reach. ${ }^{5}$

A few recent examples have begun to highlight the diverging interests of certain global cities and their host states. In the US there have also been several high profile clashes between the Trump administration, with its tendencies towards nativism and isolationism, and major cities, who view their fortunes as tied to global networks and openness. Perhaps the most telling example here has been the dispute over

\footnotetext{
${ }^{4}$ http://www.c40.org : Accessed 4.5.17

${ }^{5}$ There is a debate to be had about the extent to which cities are challenging states in different spheres of governance. Indeed, undoubtedly much of the way cities behave in new governance networks, and within the United Nations system, replicates models of state diplomacy and defers to state dominance. However, my argument here is that, despite the ways particular urban leaders and personnel think and act, there is an underlying structural logic, emerging from the tensions in the international system that I describe here, that is empowering cities, and that is generating the preconditions for 'jumping tracks'. These tensions will need to play out over the medium to long term, regardless of the intentions, perceptions or individual actions of city representatives today.
} 
immigration policy between the federal government and 'sanctuary cities'. The executive decision to strip such cities of federal funding has brought forth a show of strength from those cities, and demonstrated their capacity to resist executive power. ${ }^{6}$ Mayors in New York, Los Angeles and Chicago know that openness to migration and cultural diversity has long been a feature of successful and dynamic cities, and are loathe to go along with a direction of travel by the national executive that will damage that.

Similar dynamics were in evidence at the moment the Trump administration decided to pull out of the Paris Climate Agreement. Major cities immediately signaled that they would continue to be bound by the Paris targets, regardless of the decision of the federal government. And, despite the overall national decision to leave the European Union in the United Kingdom's referendum on membership, there was a strong preference for retaining membership in British cities. ${ }^{7}$ Cities such as London are very aware of their transnational interests, as London Mayor Khan's 'London is Open' stance in the wake of Brexit makes clear. ${ }^{8}$

If such tensions between city and state are to be found in those parts of the world with the most developed form of the Westphalian state, then problems of another degree altogether are to be seen in the Global South. Here, in the sprawling mega-cities and informal settlements, there seems to be a glaring tension between the concept of the territorial state and the vast urban formations over which the state often has incomplete knowledge and control. States often lack the capacity to govern their own territory effectively (Koonings and Kruijt 2015).

Just as there are tensions in the relationship between city and state, so too is the relation between the city and the market increasingly problematic under neoliberalism. Rampant privatization and the role of financialisation in housing markets has led to housing crises around the world. Recent activism in Boyle Heights in East Los Angeles is but one manifestation of a reaction against gentrification. More broadly, there is a growing tension between two conflicting impulses in the global city: the ability of the market to generate wealth and dynamism, and the desire for a more socially just and sustainable city.

Nowhere is this tension more visible than in the New Urban Agenda emerging from UN HABITAT III in 2016. While that document places its primary emphasis upon the role of markets as a mechanism for solving the problems that mass urbanization throws up, bringing together knowledge, entrepreneurship and innovation, it also incorporates the discourse of the 'right to the city', reflecting a desire to create cities that solve widespread social exclusion, inequality and environmental degradation, 'in which all people have equal rights and access to the benefits and opportunities that cities can offer'. ${ }^{9}$ The paradox at the heart of the UN's New Urban Agenda is that many of these social problems are generated by market externalities and market failures under neoliberal capitalism. Neoliberal market ideology - in particular,

\footnotetext{
${ }^{6}$ http://www.latimes.com/politics/la-na-pol-sanctuary-legal-battle-20170127-story.html : Accessed 30.1 .17

${ }^{7}$ https://www.thechicagocouncil.org/blog/global-insight/global-cities-brexit-london-autonomy : Accessed 10.6.17

${ }^{8}$ https://www.london.gov.uk/about-us/mayor-london/londonisopen : Accessed 15.1.18

9 http://habitat3.org/the-new-urban-agenda/ : Accessed 11.2.18
} 
extensive privatization of public assets - has tended to systematically undermine many urbanites' 'right to the city' over the last four decades, while at the same time generating inequality (Harvey 2012). Solving the paradoxical relationship between the market and the city will be key to the political life in the century of the city.

In the meantime, wealthy elites have been developing their own solution to the instabilities of global cities - secession from the everyday life of the city into vertical enclaves. As Graham (2016) has documented, there is a global trend of elites seceding from the everyday life of the city into heavily fortified spaces; increasingly, immense vertical towers act as miniature luxury cities within, yet separated from, the city. In São Paulo, for example, the residents of such towers can bypass the urban fabric entirely via the world's largest fleet of private helicopters. This trend augurs a form of global city future in which the disproportionate gains made from the market must be increasingly defended by the securitization and militarization of urban life.

The tensions between the state, market and city are only likely to increase over the course of the twenty-first century. We will not be returning to a past in which cities were firmly ensconced within national territories. The emerging form of global order is well developed, and the technologies of space/time compression that tie global cities together are not a genie that can be put back in the bottle.

But, at the same time, the global city has never been fully global. It is a reflection of processes of both hyper-connection and disconnection, of intensive integration and exclusion, of immense wealth generation and the production of poverty. It results from an uneven and bordered process, one that has built into its very logics forms of structural violence. The global city reflects the forms of liberal international order and neoliberal political economy that generated it. In the final section of this essay I want to reflect on how the capacities and capabilities that this period of global city formation has generated for cities may be refocused if this unstable system is to 'jump tracks', and form the basis of an alternative urban and international system.

\section{Jumping Tracks: Global City Futures}

In the preceding section I argued that we stand at a moment of potential crisis for global cities, but also one of opportunity. In this final section I want to outline some theoretical foundations for beginning to think through this proposition. I draw on two thinkers - separated by a gulf in time - that can offer us guidance on how to think global cities in a time of turbulence. From Karl Polanyi I draw on the insight that the pure form of market society from which global cities derive their shape must bring forth forms of reaction. Polanyi called such instances of resistance the double movement - a term describing the myriad ways in which societies try to regain control of the market and subordinate it to social needs. From Saskia Sassen I draw upon the idea that capabilities built up in one historical period can 'jump tracks', as they are reoriented and repurposed to form a different assemblage with new characteristics. In the context of this discussion, the economic, political and technological capacities developed by the global city become the capabilities that could be reoriented to a new multi-scalar political assemblage with different logics to the system of territorial nation states. Given the constraints of this short essay, this section will remain a 
suggestion for how we might build a research project oriented to understanding the sources of change in the global city.

Polanyi (1957) did not write about cities specifically, but I would contend that the global city today offers the materialized consequences of attempts to generate the form of market society that Polanyi found unsustainable, and held responsible for the collapse of nineteenth-century civilization in economic dislocation, social unrest and, eventually, world war. Polanyi had come to the conclusion that the contradictions of an untrammeled free-market liberalism must inevitably lead to multiple backlashes, as society, in various ways, tries to regain control over market forces. It is this kind of backlash that underpin some of the 'de-globalizing' impulses today.

In the post-world war period much of the West had settled upon a form of social democracy as the way to re-embed the market in society. But the resurgence of free market discourse, and eventually policy, in the neoliberalism that emerged in the 1970s has generated a new 'global' great transformation, which now seems to be bringing forth, just as in the previous period of market fundamentalism, a new set of reactions, including the rising tide of populism, and an increasing rejection of globalization. Many of those trends that Polanyi described in the earlier period appear to manifest themselves now through the materiality of contemporary global cities, but at a scale that Polanyi himself could not have imagined. And this difference in scale and spatial form between the two periods, and the capacities it enables, means that available ways out of the contradictions of market society are also different.

If Polanyi's analysis of the historical effects of the construction of a market society can lead us to believe that the system is likely to undergo a crisis induced reconstitution, then Sassen's (2006) assemblage analysis gives us the theoretical framework to understand how this transformation may be occurring. What Sassen's assemblage analysis allows us to see is how any new system must emerge from the capacities and capabilities built up within the old system. What this means for global cities is that the forms of political and economic governance capacities we have noted, as well as the technological capacities bound up with contemporary urbanism, become resources that can be reoriented to constitute the basis of a different relational system.

In the period in which contemporary global cities formed and developed, there has been a distinct shift from a system running on logics built up in the period of national states, towards a new system with global logics. And, of course, global cities have been a critical element of this shift.

Sassen's argument is that this new global formation did not emerge ex nihilum, but was incubated within the previous nationally oriented formation. Just as the 'Westphalian' system of territorial, and, later, national, states emerged via the reorientation of existing capacities built up over time in the medieval period, ${ }^{10}$ so this globally oriented system emerges from the reorientation of capacities lodged deep within the national state; such as the building of international institutions, and the

\footnotetext{
${ }^{10}$ In particular, she traces the construction of a number of proto-capabilities in the medieval period that later get reoriented to form the basis of national states: power as legitimate authority, monetization, centralized bureaucratic structures, urban territoriality, and new subjectivities.
} 
creation of state bureaucracies whose competences have been reoriented to global projects. Critically, capabilities built up in one era can be shifted towards objectives other than the original ones for which they were developed.

Such systems, then, are not unitary. Rather, they are assemblages, comprising distinct elements, with variable capabilities that can develop in new ways when plugged into new assemblages, or combined with other components in new relational formations. Sassen argues that components are multi-valent: changing the valence of enough components can potentially reorient the system if a tipping-point is reached. It is at this point that a system can jump tracks - resulting in a historic, epochal transformation.

For Sassen, it is apparent that a tipping-point threshold has been crossed. The 'national' has been partially 'unbundled', and will not be re-assembled on the old models. But, despite the prominence of rhetoric about 'de-globalization', we cannot go back to the nationally bounded system of the post-war period. We must look not to the past, or to the continuation of the present form of globalization, but to a future with different logics. It is here that the immense changes in urban life over the last forty years offer the prospect of real transformation; a prospect yet to be fully appreciated.

In this sense we might come to see the current form of the global city as a form of chrysalis in which new governance capacities are being developed. Such capacities can be reoriented, with potentially transformative impacts on cities, states and the wider international system. In the preceding sections we have seen how global cities now have an array of governance capacities in the economic and political domains, as well as a range of technological capacities. Together, and in combination, these capacities have opened up the possibility space for a variety of scale jumping sociotechnical assemblages to form (DeLanda 2006). We have seen initial rudimentary variants emerge in the scale-jumping city-networks and city diplomacy of the C40 and others, discussed earlier. Such socio-technical assemblages arise partially from a pressing need to match the complexity and scale of global problems, such as climate change, that the territorially scaled state system cannot adequately address. So, in the type of exploration of the possibility spaces of scale-jumping socio-technical assemblages represented by the $\mathrm{C} 40$, we see that marrying density to information technology might generate transnational networks of smart-cities that can work to reduce urban environmental footprints. The Internet of Things, smart grids, sensors and big data form an array of interlinked technologies that offer the potential for greater control over the dynamics of urban development, while networked governance and city diplomacy offer the possibility to replicate and extend their impact.

Eventually a more developed socio-technical assemblage might potentially look something like Barber's Global Parliament of Mayors - but only after a long period of time in which cities develop their scale-jumping capacities, foster new forms of identity, and resolve tensions with states. Such a developed form would require a very long period of time to crystallise. However, despite the weakness of any nominally existing 'parliament' ${ }^{11}$ in the contemporary world, it is significant that the concept has

\footnotetext{
${ }^{11} \mathrm{https://globalparliamentofmayors.org} \mathrm{:} \mathrm{accessed} \mathrm{16.2.18}$
} 
arisen in the contemporary period, giving name to the emergence of the possibility, and one might argue, structural requirement, of an assemblage of this nature.

If the capacities of cities have been augmented in ways that suggest new and transformative possibilities, then the motivation to 'jump tracks' has also been building, as a Polanyian analysis shows. This is where the question of 'deglobalization' becomes pertinent. Political attempts to re-embed the market in society today must run through global cities, because they are its primary driving and coordinating force. This is where the importance of redesigning and repurposing cities and their technological and governance components becomes an opportunity to create a new basis for the system.

The question of how and where global city capacities can be reoriented and reconfigured will be one that will become an object of political struggle over the coming decades. The actual future emerging from the possibility space of various socio-technical assemblages is not guaranteed to be a progressive one. Indeed, many of the directions that the Polanyian double movement took in the early twentieth century brought with them appalling consequences.

In the contemporary global city we see multiple futures struggling to be born. One set offers a more progressive vision, grouped under the moniker of 'the right to the city', and emphasizing social justice, environmental sustainability, the protection of ecosystems, poverty reduction, equality and livability. Technological capacities offer possibilities to develop sustainable and resilient forms of urban life, or to develop efficient sharing economies. But, at the same time, technologies develop within social systems, not independently of them, and such technologies would need to be repurposed, beyond the form of free market capitalism in which they have developed, if they are to push the system to 'jump tracks' (Mason 2016).

Alternatively, a purely technocratic and authoritarian inflected valence for these emerging capacities would mean an extension and intensification of the forms of structural violence inherent to the neoliberal city. Authoritarian responses to the instabilities accompanying global capitalism offer an alternative set of possibilities for the emergence of new assemblages, including the intensified securitization of privatized spaces, the continuing secession of elites from the urban commons, and the further entrenchment of inequality.

Whatever the outcome of such struggles, the future frameworks for modern societies - technological, political, and economic - will be something new. A new iteration of the city will be at the heart of any new system. 


\section{References}

Acuto, M. (2011). 'Finding the Global City: An Analytical Journey Through the “Invisible College'. Urban Studies 48(14): 2953-73.

Acuto, M. (2013). Global cities, governance and diplomacy : the urban link. Abingdon, Oxon. ; New York, NY, Routledge.

Acuto, M. and S. Curtis (2014). Reassembling international theory: assemblage thinking and international relations. London, Palgrave.

Acuto, M. and Rayner, S. (2016), City networks: breaking gridlocks or forging (new) lock-ins? International Affairs 92: 1147-1166.

DeLanda, M. (2006). A New Philolosophy of Society: Assemblage Theory and Social Complexity. London. Continuum.

Barber, B. (2013). If mayors ruled the world : dysfunctional nations, rising cities. Yale University Press.

Bellamy Foster, J. (2000) Marx's Ecology: Materialism and Nature. New York. Monthly Review Press

Bookchin, M. (1992). Urbanization without cities : the rise and decline of citizenship. Montréal ; New York, Black Rose Books.

Bouteligier, S. (2013). Cities, networks, and global environmental governance : spaces of innovation, places of leadership. New York, Routledge.

Brenner, N. and R. Keil (2006). The global cities reader. London, Routledge.

Brenner, N. and C. Schmid (2011). Planetary Urbanisation. Urban Constellations. Berlin, Jovis.

Curtis, S. (2016) Global Cities and Global Order. Oxford. Oxford University Press.

Davis, M. (2006). Planet of slums. London; New York, Verso.

Ferguson, N and F. Zakaria (2017). The End of the Liberal Order? London, Oneworld.

Friedmann, J. (1986). "The World City Hypothesis." Development and Change 17: 69-83.

Gilbert, J. (2013). "What kind of thing is neoliberalism?”. New Formations. 80/81 722

Gill, S. (2003). Power and resistance in the new world order. Houndmills, Basingstoke, Hampshire ; New York, Palgrave Macmillan. 
Gindin, S. and L. Panitch (2013). The making of global capitalism : the political economy of American empire. New York, Verso.

Glaeser, E. (2011). Triumph of the city. London, Macmillan.

Graham, S. (2010). Cities under siege : the new military urbanism. London, Verso.

Graham, S. (2016). Vertical : The City from Satellites to Bunkers. New York, Verso.

Graham, S. and S. Marvin (2001). Splintering urbanism : networked infrastructures, technological mobilities and the urban condition. London, Routledge.

Harvey, D. (2012). Rebel cities : from the right to the city to the urban revolution. New York, Verso.

Hurrell, A. (2007). On global order: power, values, and the constitution of international society. Oxford, Oxford University Press.

Ikenberry, J. (2011) Liberal Leviathan : The Origins, Crisis, and Transformation of the American World Order (Woodstock: Princeton University Press).

Koonings, K. and D. Kruijt, (2015). Urban fragility and resilience in Latin America: conceptual approaches and contemporary patterns. In Kees Koonings \& Dirk Kruijt (Eds.), Violence and resilience in Latin American cities London: Zed Books.

Khanna, P. (2016) Connectography: Mapping the Future of Global Civilization. New York. Random House.

Latour, B. (1993). We have never been modern. Hemel Hempstead, Harvester Wheatsheaf.

Lefebvre, H. (1991). The production of space. Oxford ; Cambridge, MA., Blackwell.

Mason, P. (2016). PostCapitalism: A Guide to our Future. New York. Verso.

McGuirk, J. (2014). Radical cities : across Latin America in search of a new architecture. London, Verso.

Polanyi, K. (1957). The great transformation : the political and economic origins of our time. Boston, MA, Beacon Press.

Polèse, M. (2011). The wealth and poverty of regions : why cities matter. Chicago, Ill. ; London, University of Chicago Press.

Sassen, S. (1991). The global city : New York, London, Tokyo. Princeton, Princeton University Press.

Sassen, S. (2006). Territory, authority, rights: from medieval to global assemblages. Princeton, Princeton University Press. 
Sassen, S. (2014). Expulsions : Brutality and Complexity in the Global Economy. Cambridge, MA. Harvard University Press.

Soja, E. W. (2000). Postmetropolis : critical studies of cities and regions. Oxford ; Malden, MA, Blackwell.

Taylor, P. (2003). World city network : a global urban analysis. London, Routledge.

Taylor, P. (2013). Extraordinary cities: millennia of moral syndromes, world-systems and city/state relations. Cheltenham, Edward Elgar. 